\title{
Removal of Atrazine from Water Using Oil Palm Shell Based Adsorbents: Equilibrium and Kinetic Study
}

\author{
H. T. Moh ${ }^{1}$, Ivy A. W. Tan ${ }^{2}$, and Leonard L. P. Lim $^{3}$
}

\begin{abstract}
Adsorption using granular activated carbon (GAC) in a permeable reactive barrier (PRB) has been proven in inhibiting the further spread of contaminant plumes in groundwater. GAC synthesized from oil palm shell was chosen for groundwater remediation in this study due to the low operation cost using the adsorption process. In this study, GAC synthesized from oil palm shells were used as adsorbent to adsorb atrazine from water. This study involved a series of batch experiment to determine the adsorption equilibrium and kinetics of adsorbent. The batch experiment was conducted by shaking conical flasks containing $0.6 \mathrm{~g}$ GAC in $300 \mathrm{~mL}$ solution with initial atrazine concentrations of $5,10,20$ and $30 \mathrm{mg} / \mathrm{L}$ at $180 \mathrm{rpm}$ at $30 \pm 2{ }^{\circ} \mathrm{C}$. The GAC showed more than $95 \%$ of atrazine removal in all the batch experiments. The adsorption kinetic study showed that the adsorption of atrazine is of physisorption as the experimental data is fitted better to the pseudo-first-order model than the pseudosecond-order model. In the adsorption isotherm study, the adsorption of atrazine onto GAC was better described by the Freundlich model which indicated multilayer adsorption on the heterogeneous surface of the adsorbent. The atrazine adsorption capacity of the GAC was $15.132 \mathrm{mg} / \mathrm{g}$, which was higher than that using the activated carbon synthesized from waste charcoal (13.947 $\mathrm{mg} / \mathrm{g})$. This study shows that there is a potential for GAC to be used for remediating groundwater contaminated by pesticides.
\end{abstract}

Keywords: granular activated carbon, atrazine, batch experiment, equilibrium study, kinetic study

\section{INTRODUCTION}

$\mathrm{P}_{\mathrm{r}}^{\mathrm{s}}$ ESTICIDES are the major contribution in today's intensive agriculture [1]. The use of pesticides beyond maximum residue level (MRL) in agricultural sectors could cause contamination of groundwater and surface water resources due to their leaching and runoff losses [1]-[4]. Pesticides were persistence in groundwater due to its resistance to natural degradation processes and have been classified as persistent organic pollutants (POPs) [3], [5], [6]. POPs have been known as an increasing problem in water supplies [6]. Groundwater contamination by pesticides can negatively affect the human reproductive systems if consumed as it is being directly used for drinking purpose [1], [2]. Therefore, there is a need to remediate the groundwater due to its severe impact.

There are various technologies available to remove pesticides from groundwater such as pump-and-treat and air sparging [7]. Some of the technologies have to combine together such as air sparging and soil vapor extraction in order to reach the desire clean up level and this will increase the remediation cost. In addition, the efficiency of those technologies was limited by soil heterogeneity [8], [9]. However, the groundwater remediation which is not affected by soil heterogeneity is the permeable reactive barrier (PRB). PRB is a trench with used of adsorbent as reactive material to inhibit migration of contaminants plume [10], [11]. Adsorption process had been used in PRB to remove pesticides in groundwater [10]-[12].

Adsorption is a physical process involving the attraction of contaminant molecules onto the surface of the adsorbent [7]. Adsorption technology such as PRB was being widely used presently to remove pesticides from the groundwater due to high removal efficiency and does not produce harmful by-products [13]-[15]. The commercial industrial adsorbent is granular activated carbon (GAC) which is widely used adsorbent in removing organic contaminants from water [4], [16]. GAC were widely used in the treatment of wastewater due to it advantageous of physiochemical properties including excellent mechanical strength, chemical stability in different media and distributing large pore size in addition to its wide specific surface area [4]. The treatments by using GAC as adsorbent had successfully removed the pesticides of aldrin, ametryn and applaud by $98 \%, 75 \%$ and $80 \%$, respectively [17].

Adsorption is suitable for adsorb the contaminants from groundwater due to slow groundwater flow (33 $\mathrm{m} /$ year) [18]. This means that long residence time and slow migration of contaminant groundwater to flow through the PRB. There is a potential use of GAC synthesized from oil palm shell for groundwater remediation due to the low operation cost using an adsorption process. Adsorption process is considered better due to easiness of operation, simplicity of design and can remove different

\footnotetext{
${ }^{1}$ H. T. Moh is from the Department of Civil Engineering, Faculty of Engineering, UNIMAS, 94300 Kota Samarahan, Sarawak, Malaysia.

${ }^{2}$ Ivy A. W. Tan is from the Department of Chemical Engineering, Faculty of Engineering, UNIMAS, 94300 Kota Samarahan, Sarawak, Malaysia.

${ }^{3}$ Leonard L. P. Lim is from the Department of Civil Engineering, Faculty of Engineering, UNIMAS, 94300 Kota Samarahan, Sarawak, Malaysia.
} 


\section{UNIMAS e-Journal of Civil Engineering: Volume 4, Issue 2}

type of pollutants [19]. Some of the adsorbents synthesized from agriculture wastes have shown promising results in adsorption of contaminants from water. Adsorbent derived from coconut husk activated carbon and fly ash adsorbed 434.78 $\mathrm{mg} / \mathrm{g}$ methylene blue and $27.9 \mathrm{mg} / \mathrm{g}$ phenol, respectively [20], [21].

Therefore, adsorbent and GAC synthesized from the oil palm shell is used as the raw material in this study due to the significant amount of oil palm waste in Sarawak, being a major contributor to Malaysian oil palm production of $12.8 \%$ (2.18 million tonnes) in 2011, and is projected to increase [22]. The use of oil palm shell can help to reduce the amount of oil palm wastes to be disposed, therefore contributing to environmental protection. In batch experiment, the adsorption capacity and efficiency of the adsorbent was tested on removing atrazine from the water.

\section{MATERIAL AND METHODS}

\section{Adsorbent}

Commercially available GAC synthesized from oil palm shell as adsorbent was obtained from Bravo Green Sdn. Bhd. and is located at Kota Samarahan. The size for this GAC used was at ranged from 1.68 to $3.36 \mathrm{~mm}$ (US mesh $-6 \times 12$ ).

\section{Target Contaminant}

Atrazine (Fluka 45330) was used to represent the pesticides in this study. The initial concentrations of atrazine in this study were 5, 10, 20 and $30 \mathrm{mg} / \mathrm{L}$.

\section{Batch Experiment}

The batch experiment had been carried out to determine the adsorption capacity of the GAC synthesized from oil palm shells. Adsorption capacity is conducted by using $0.6 \mathrm{~g}$ of GAC with $300 \mathrm{~mL}$ of atrazine solution in conical flask with different concentrations. The various initial concentrations of atrazine in this study were 5, 10, 20 and $30 \mathrm{mg} / \mathrm{L}$. The conical flasks then were placed into the refrigerated incubating shaker (Thermo Scientific) at temperature $\left(30 \pm 2{ }^{\circ} \mathrm{C}\right)$ for 25 hours at $180 \mathrm{rpm}$ in order to achieve equilibrium. The initial and final $\mathrm{pH}$ of the solutions was measured by using $\mathrm{pH}$ meter $(\mathrm{Oakton} \circledast$ Waterproof Eco TestrTM pH 2).

\section{Sample Analysis}

For the sample analysis, the samples were filled into $4 \mathrm{~mL}$ quartz cell cuvette. Then, the quartz cell cuvette was placed into UV-visible spectrophotometer to analyze. The temperature of the analyzed was at $22 \pm 2{ }^{\circ} \mathrm{C}$. Methanol was added into the solution to emulsify the atrazine in water samples to analyze. Methanol is an organic solvent and will break up the pesticides into smaller droplets so that it is easier to be detected.

\section{RESULTS AND DISCUSSION}

\section{Effect of Initial Concentration of Atrazine on Adsorption Equilibrium}

Figure 1 shows the effect of various initial concentrations of atrazine on the adsorption of atrazine by the GAC at $30{ }^{\circ} \mathrm{C}$. The atrazine adsorption was fast at the initial stages of the experiment but become slower when nearing to the equilibrium point. In all the experiments, the equilibrium point occurred about 240 minutes after the experiment started, whereby the curve reached a plateau. The adsorption of atrazine reached a state of dynamic equilibrium in which there was no change in the concentration of atrazine. The equilibrium concentrations $\left(\mathrm{C}_{\mathrm{e}}\right)$ were $0.079,0.142,0.122$ and $0.428 \mathrm{mg} / \mathrm{L}$ for initial atrazine concentrations of 5, 10, 20 and $30 \mathrm{mg} / \mathrm{L}$, respectively.

The amount of atrazine adsorbed at the equilibrium time show that the maximum adsorption capacity of the GAC under the operating condition applied. Adsorption capacity of the GAC was due to the number of vacant surface sites were available for adsorption. During the initial stage, atrazine adsorption was fast because there was large number of vacant surface of GAC were available for adsorption. Atrazine molecules moved through the firm surrounding of the external surface of GAC, the molecules then diffuse from the external surface into the pores of the GAC. At final stage, the molecules are adsorbed on the active sites located at the internal surface within the pores and the atrazine adsorption become equilibrium because remaining vacant surface of GAC were difficult to be occupied due to repulsive forces between the solute molecules on the solid and bulk phases [23], [24].

In this study, the adsorption at equilibrium, $\mathrm{q}_{\mathrm{e}}$, increased from 2.963 to $15.132 \mathrm{mg} / \mathrm{g}$ with an increase in initial concentration from 5 to $30 \mathrm{mg} / \mathrm{L}$. When the initial atrazine concentration was increased, the mass transfer force would become larger and resulting in higher atrazine adsorption [23]. 
UNIMAS e-Journal of Civil Engineering: Volume 4, Issue 2

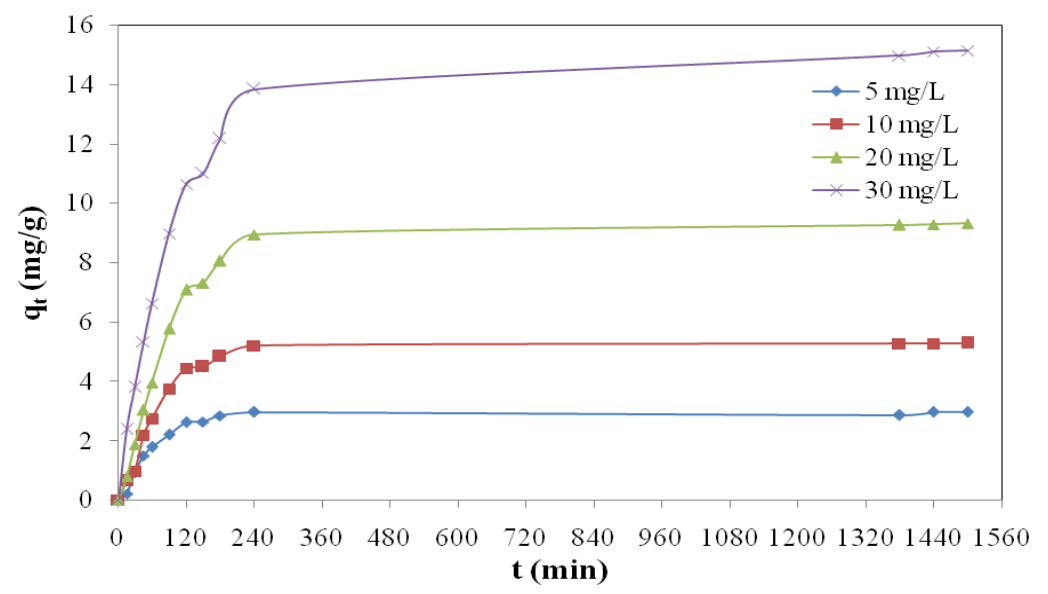

Figure 1: Adsorption of atrazine using GAC at $30^{\circ} \mathrm{C}$ at initial concentrations of $5,10,20$ and $30 \mathrm{mg} / \mathrm{L}$

\section{Adsorption Kinetic Studies}

There are two models were used to studies the rate of adsorbate uptake on GAC and it controls the equilibrium time [23]. Pseudo-first-order (Equation (1)) [25] and pseudo-second-order (Equation (2)) [26] kinetic models were used to evaluate the mechanism of the adsorption process and study the kinetics of the adsorption process.

$\ln (\mathrm{qe}-\mathrm{qt})=\ln \mathrm{qe}-\mathrm{k} 1 \mathrm{t}$

$\mathrm{t} / \mathrm{q}_{\mathrm{t}}=1 /\left(\mathrm{k}_{2} \mathrm{qe}_{2}\right)+\left(1 / \mathrm{q}_{\mathrm{e}}\right) \mathrm{t}$

Where $\mathrm{q}_{\mathrm{e}}(\mathrm{mg} / \mathrm{g}), \mathrm{q}_{\mathrm{t}}(\mathrm{mg} / \mathrm{g})$ are amounts of atrazine adsorbed onto activated carbon per unit mass of activated carbon at equilibrium and at any time $\mathrm{t}(\mathrm{min})$, respectively. $\mathrm{k}_{1}(1 / \mathrm{min})$ and $\mathrm{k}_{2}(\mathrm{~g} / \mathrm{mg} \mathrm{min})$ are the rate constants of pseudo-first-order and pseudo-second-order adsorptions, respectively. The linear plot of pseudo-first-order is shown in Figure 2 and the linear plot of pseudo-second-order is as shown in Figure 3, the two plots are more likely to evaluate the mechanism of the adsorption process.

Table 1 shows the data for pseudo-first-order and pseudo-second-order kinetic. The linear plot of ln $\left(q_{e}-q_{t}\right)$ versus $t$ in Figure 2 gave the slope of $\mathrm{k}_{1}$ and intercept of $\ln \mathrm{q}_{\mathrm{e}}$. The values for $\mathrm{q}_{\mathrm{e}}, \mathrm{k}_{1}$ and correlation coefficient, $\mathrm{R}^{2}$ obtained from the graph for adsorption of atrazine using GAC at $30{ }^{\circ} \mathrm{C}$ were recorded in Table 1 . This procedure was done to determine the behavior over the whole range of adsorption. The values between the experimental $\mathrm{q}_{\mathrm{e}}$ and the calculated qe in Table 1 were quite similar. Moreover, the correlation coefficient, $\mathrm{R}^{2}$ values for the first-order kinetic model were almost equal to unity for all atrazine concentrations. The correlation coefficient, $\mathrm{R}^{2}$ values were in the range from 0.811 to 0.989 for atrazine initial concentration of 5 to $30 \mathrm{mg} / \mathrm{L}$ Hence, this shows the applicability of the first-order kinetic model to describe the adsorption process of atrazine using GAC.

Table 1: Pseudo-first-order and pseudo-second-order kinetic rate constants at different initial concentration for adsorption of atrazine using $\mathrm{GAC}$ at $30^{\circ} \mathrm{C}$

\begin{tabular}{|c|c|c|c|c|c|c|c|c|}
\hline \multirow[b]{2}{*}{$\begin{array}{l}\text { Initial } \\
\text { Conc. } \\
\text { (mg/L) }\end{array}$} & \multirow[b]{2}{*}{$\begin{array}{l}q_{\mathrm{e}} \exp . \\
(\mathrm{mg} / \mathrm{g})\end{array}$} & \multirow[b]{2}{*}{$\begin{array}{c}\% \\
\text { Removal }\end{array}$} & \multicolumn{3}{|c|}{ Pseudo-first-order parameter } & \multicolumn{3}{|c|}{ Pseudo-second-order parameter } \\
\hline & & & $\begin{array}{c}q_{\mathrm{e}} \text { calc. } \\
(\mathrm{mg} / \mathrm{g})\end{array}$ & $\begin{array}{c}\mathbf{k}_{1} \\
\left(\mathrm{~min}^{-1}\right)\end{array}$ & $\mathbf{R}^{2}$ & $\begin{array}{c}\mathrm{q}_{\mathrm{e}} \\
\text { calc. } \\
(\mathrm{mg} / \mathrm{g})\end{array}$ & $\begin{array}{c}\mathbf{k}_{2} \\
\text { (g/mg/ } \\
\text { min) }\end{array}$ & $\mathbf{R}^{2}$ \\
\hline 5 & 2.963 & 98.684 & 6.586 & 0.029 & 0.811 & 6.757 & $6.170 \times 10^{-4}$ & 0.356 \\
\hline 10 & 5.275 & 98.672 & 6.469 & 0.016 & 0.971 & 10.417 & $4.740 \times 10^{-4}$ & 0.746 \\
\hline 20 & 9.315 & 99.349 & 10.892 & 0.012 & 0.978 & 22.727 & $1.388 \times 10^{-4}$ & 0.704 \\
\hline 30 & 15.132 & 98.605 & 15.180 & 0.009 & 0.989 & 21.277 & $3.650 \times 10^{-4}$ & 0.990 \\
\hline
\end{tabular}

The linear plot of $t / q_{t}$ versus $t$ in Figure 3 gave the slope of $1 / q e$ and intercept of $1 /\left(k_{2} q_{2}\right)$. The values for $q_{e}$, $k_{1}$ and correlation coefficient, $\mathrm{R}^{2}$ obtained from the graph for adsorption of atrazine using GAC at $30{ }^{\circ} \mathrm{C}$ were recorded in Table 1 . This procedure was done to determine the behavior over the whole range of adsorption. The values between the experimental $\mathrm{q}_{\mathrm{e}}$ and the calculated $\mathrm{q}_{\mathrm{e}}$ in Table 1 were quite different. Moreover, the correlation coefficient, R2 values for the second-order kinetic model were relatively small. The correlation coefficient, $\mathrm{R}^{2}$ values were in the range from 0.356 to 0.990 for atrazine initial concentration of 5 to $30 \mathrm{mg} / \mathrm{L}$ Hence, this shows that the adsorption of atrazine using GAC is not a second-order reaction. 
UNIMAS e-Journal of Civil Engineering: Volume 4, Issue 2

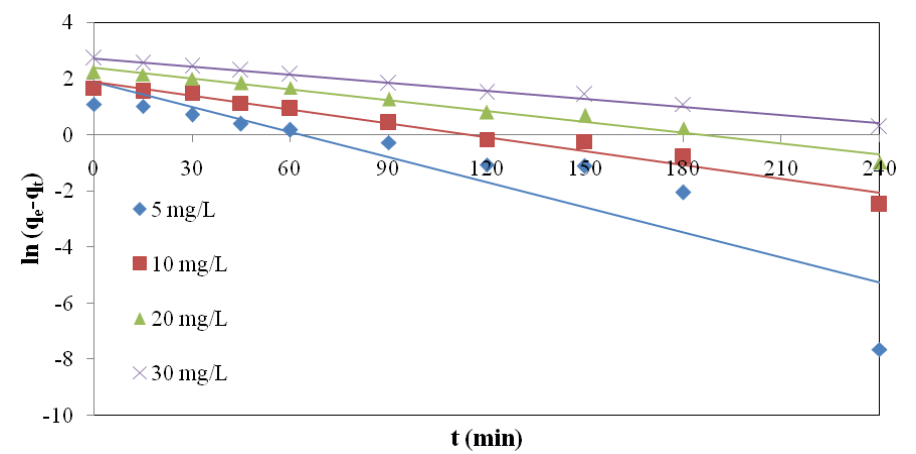

Figure 2: Pseudo-first-order kinetics for adsorption of atrazine using GAC at $30{ }^{\circ} \mathrm{C}$

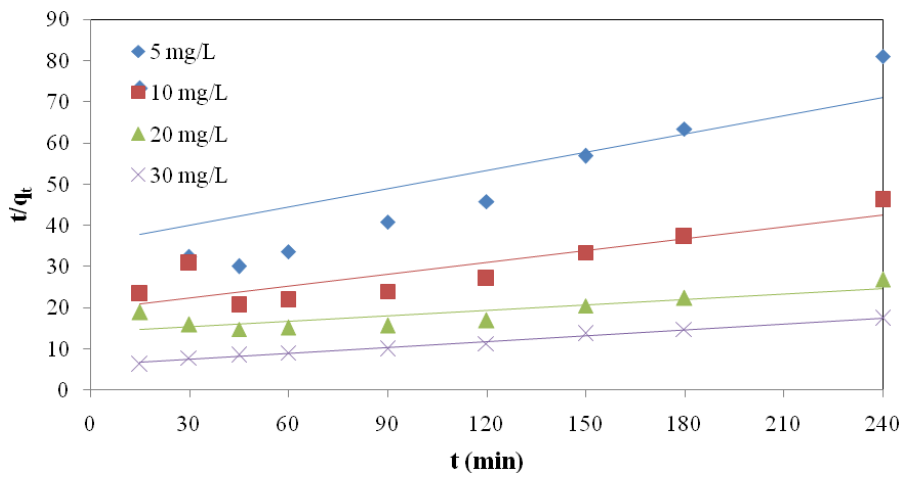

Figure 3: Pseudo-second-order kinetics for adsorption of atrazine using $\mathrm{GAC}$ at $30{ }^{\circ} \mathrm{C}$

\section{Adsorption Isotherms}

There are two models were used to explain the experimental data for the adsorption isotherms in this study. Adsorption isotherms are used to describe how the molecules of adsorbates interact with adsorbent surface. Langmuir (Equation (3)) [24] and Freundlich isotherms (Equation (4)) [24] were used to evaluate the type of adsorbent surface.

$\mathrm{C}_{\mathrm{e}} / \mathrm{q}_{\mathrm{e}}=1 /\left(\mathrm{Q}_{0} \mathrm{~K}_{\mathrm{L}}\right)+\left(1 / \mathrm{Q}_{0}\right) \mathrm{C}_{\mathrm{e}}$

$\mathrm{Q}_{0}(\mathrm{mg} / \mathrm{g})$ and $\mathrm{K}_{\mathrm{L}}(\mathrm{L} / \mathrm{mg})$ are Langmuir constants in relevant to maximum monolayer adsorption capacity onto a surface with no transmigration of adsorbates in the surface [27], [28].

$\log \mathrm{q}_{\mathrm{e}}=\log \mathrm{K}_{\mathrm{F}}+(1 / \mathrm{n}) \log \mathrm{C}_{\mathrm{e}}$

$\mathrm{K}_{\mathrm{F}}$ and $\mathrm{n}$ are Freundlich constants in relevant to the adsorption capacity on a heterogeneous surface or surfaces supporting sites of varied affinity and how favourable the adsorption process assuming that the stronger binding sites are occupied first and that the binding strength decreases with the increasing degree of site occupation, respectively [23], [27]. The slope of 1/n is used to measure the adsorption intensity or surface heterogeneity which ranging between 0 and 1 , the surface become more heterogeneous as the value closer to zero [24]. The other important characteristic of Langmuir isotherm is a dimensionless constant, separation factor, $\mathrm{R}_{\mathrm{L}}$, which can be calculated from the Equation (5) [24].

$\mathrm{R}_{\mathrm{L}}=1 /\left(1+\mathrm{K}_{\mathrm{L}} \mathrm{C}_{0}\right)$

Where $\mathrm{K}_{\mathrm{L}}$ is the Langmuir constant and $\mathrm{C}_{0}$ is the highest dye concentration $(\mathrm{mg} / \mathrm{L})$. The value of $\mathrm{R}_{\mathrm{L}}$ can indicate the type of isotherm to be either unfavorable $\left(R_{L}>1\right)$, linear $\left(R_{L}=1\right)$, favorable $\left(0<R_{L}<1\right)$ or irreversible $\left(R_{L}=0\right)$ [24].

Table 2 shows the data for the Langmuir and Freundlich isotherms. The linear plot of $\mathrm{C}_{\mathrm{e}} / \mathrm{q}_{\mathrm{e}}$ versus Ce in Figure 4 gave the slope of $1 / \mathrm{Q}_{0}$ and intercept of $1 /\left(\mathrm{Q}_{0} \mathrm{~K}_{\mathrm{L}}\right)$. The values for the coefficient correlation, $\mathrm{R}^{2}$, adsorption capacity, $\mathrm{Q}_{0}$ and energy of adsorption, $\mathrm{K}_{\mathrm{L}}$ can be calculated from the linear plot in Figure 4 and were recorded in Table 2. The value for $\mathrm{R}^{2}$ obtained from the graph was 0.153 , less than that of Freundlich isotherm and indicating less favorable adsorption of atrazine onto GAC using the Langmuir isotherm. The value of $\mathrm{Q}_{0}$ was $58.824 \mathrm{mg} / \mathrm{g}$ and indicating not a very strong monolayer adsorption to the surface. The value for $\mathrm{K}_{\mathrm{L}}$ was $0.85 \mathrm{~L} / \mathrm{mg}$ and indicating less favorable sorption energy.

The Freundlich constants are related to the sorption capacity, $\mathrm{K}_{\mathrm{F}}$ and intensity, $\mathrm{n}$. These constants can be calculated from the linear plot in Figure 5 and were recorded in Table 2. The linear plot of $\log \mathrm{q}_{\mathrm{e}}$ versus $\log \mathrm{C}_{\mathrm{e}}$ in Figure 5 gave the slope of $1 / \mathrm{n}$ and intercept of $\log \mathrm{K}_{\mathrm{F}}$. The high value for $\mathrm{K}_{\mathrm{F}}$ obtained from the graph was $33.266 \mathrm{~L} / \mathrm{mg}$ and indicating favorable adsorption conditions for atrazine in aqueous solution. The value for $\mathrm{R}^{2}$ obtained from the graph was 0.749 , higher than that of Langmuir isotherm and indicating favorable adsorption of atrazine onto GAC using the Freundlich isotherm. 
UNIMAS e-Journal of Civil Engineering: Volume 4, Issue 2

Table 2: Langmuir and Freundlich isotherm parameter constants for adsorption of atrazine using GAC at $30^{\circ} \mathrm{C}$

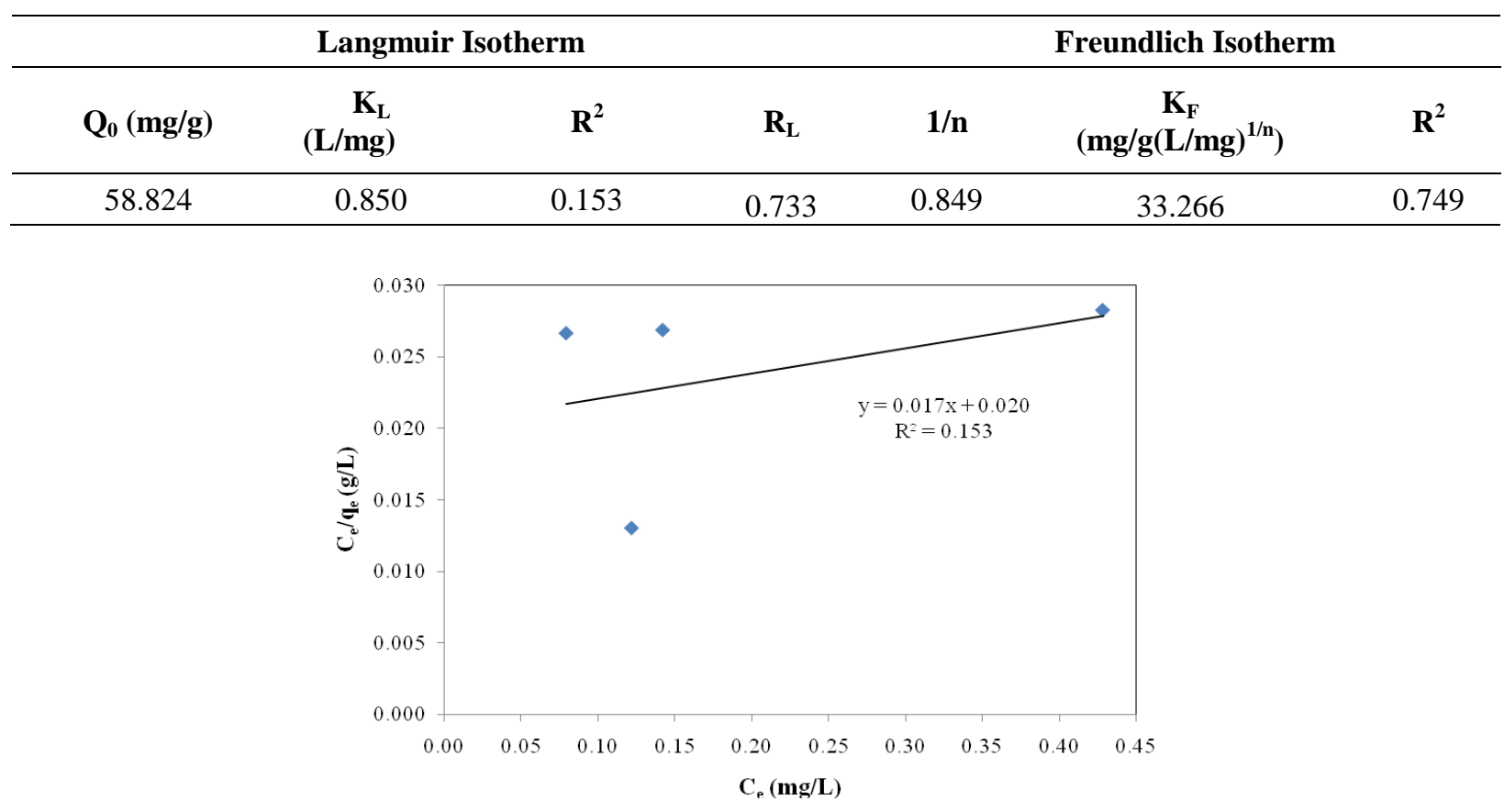

Figure 4: Langmuir isotherm for adsorption of atrazine using GAC at $30^{\circ} \mathrm{C}$

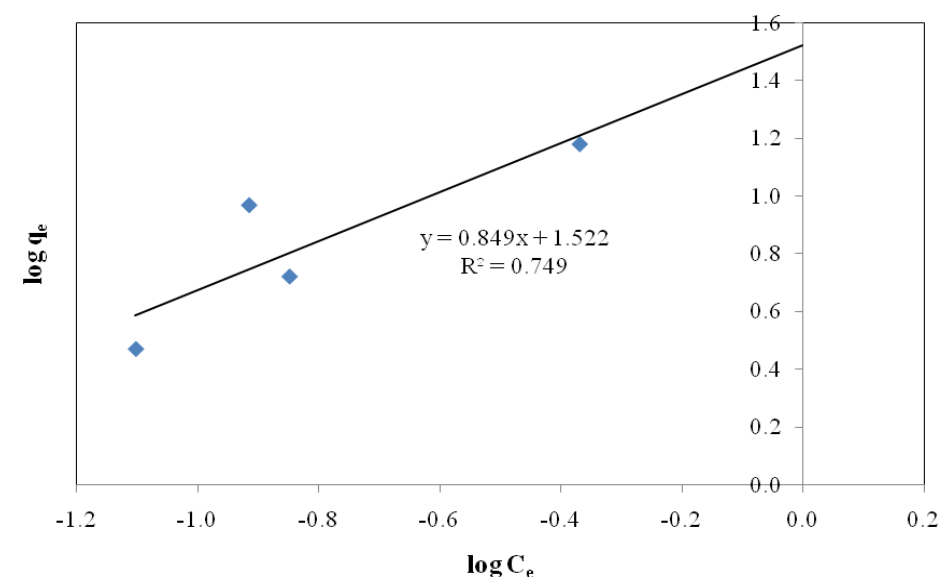

Figure 5: Freundlich isotherm for adsorption of atrazine using $\mathrm{GAC}$ at $30^{\circ} \mathrm{C}$

\section{CONCLUSION}

This study showed that the GAC synthesized from oil palm shell was able to remove atrazine from water. The GAC achieved more than $95 \%$ atrazine removal in all the batch experiments. In the adsorption kinetics study, GAC synthesized from oil palm shells showed the adsorption of atrazine was of the pseudo-first-order which implies physisorption. In the adsorption isotherm study, the adsorption of atrazine was betters described by the Freundlich isotherm, indicating multilayer adsorption on the heterogeneous surface of the adsorbent. The atrazine adsorption capacity of GAC was $15.132 \mathrm{mg} / \mathrm{g}$.

\section{ACKNOWLEDGMENT}

We would like to thank Universiti Malaysia Sarawak (UNIMAS) for funding this research through the Small Grant Scheme (grant no. 02(S84)/820/2011(18)) and Bravo Green Sdn. Bhd. for providing the GAC.

\section{REFERENCES}

[1] Neera, S. (2009). Adsorption of Herbicides on Coal Fly Ash from Aqueous Solutions. Journal of Hazardous Materials, 168, $233-237$.

[2] Rengam, S. V. (2008). Malaysia: Severe Health Effects of Pesticides on Workers in Oil Palm Plantations. Montevideo: World Rainforest Movement's Bulletin.

[3] Pilo, W. (2011). Expert: Beware of Pesticide Contamination. The Borneo Post, 9.

[4] Salman, J. M., Njoku, V. O. and Hameed, B. H. (2011). Batch and Fixed-Bed Adsorption of 2, 4-Dichlorophenoxyacetic Acid onto Oil Palm found Activated Carbon. Chemical Engineering Journal, 174, 33-40. 


\section{UNIMAS e-Journal of Civil Engineering: Volume 4, Issue 2}

[5] Ivana, G., Marko, M., Dinko, V. and Natalija, K. (2009a). Evaluation of Atrazine Degradation in UV/FeZSM-5/ $\mathrm{H}_{2} \mathrm{O}_{2}$ System Using Factorial Experimental Design. Chemical Engineering Journal, 150, 476-484.

[6] Ivana, G., Natalija, K. and Dinko, V. (2009b). Removal of Atrazine Herbicide from Model Wastewater. Technologia Quimica, 29 , 32-42.

[7] Liu. (1997). Environmental Engineer Handbook, 2nd Ed. Boca Raton, Florida: Louis Publishers.

[8] Tomlinson, D. W., Thomson, N. R., Johnson, R. L. and Redman, J. D. (2003). Air Distribution in the Borden Aquifer During In Situ Air Sparging. Journal of Contaminant Hydrology, 67, 113-132.

[9] Khan, F. I., Hejazi, R. and Husain, T. (2004). An Overview and Analysis of Site Remediation Technologies. Journal of Environmental Management, 71, 95-122.

[10] Craig, J. R., Rabideau, A. J. and Suribhatla, R. (2006). Analytical Expressions for the Hydraulic Design of Continuous Permeable Reactive Barriers. Advances in Water Resources, 29, 99-111.

[11] Hemsi, P. S. and Shackelford, C. D. (2006). An Evaluation of the Influence of Aquifer Heterogeneity on Permeable Reactive Barrier Design. Water Resources Research, 42, W03402.

[12] Plagentz, V., Ebert, M. and Dahmke, A. (2006). Remediation of Groundwater Containing Chlorinated and Brominated Hydrocarbons, Benzene and Chromate by Sequential Treatment Using ZVI and GAC. Environmental Geological, 49, 684-695.

[13] Gupta, V. K., Ali, I. and Saini, V. K. (2006). Adsorption of 2,4-D and Carbofuran Pesticides Using Fertilizer and Steel Industry Wastes. Journal Colloid Interface Science, 299, 556-563.

[14] Memon, G. Z., Bhanger, M. I., Akhtar, M., Talpur, F. N. and Memon, J. R. (2008). Adsorption of Methyl Parathion Pesticide from Water Using Watermelon Peels as a Low Cost Adsorbent. Chemical Engineering Journal, 138, 616-621.

[15] Liu, W., Zhang, J., Zhang, C., Wang, Y. and Li, Y. (2010). Adsorptive Removal of Cr (VI) by Fe Modified Activated Carbon Prepared from Trapa Natans Husk. Chemical Engineering Journal, 162, 677-684.

[16] Jones, L. R., Owen, S. A., Horrell, P. and Burns, R. G. (1997). Bacterial Inoculation of Granular Activated Carbon Filters for the Removal of Atrazine from Surface Water. Water Resources, 32, 2542-2549.

[17] Dessouki, A., Aly, H. and Sokker, H. (1999). The Use Gamma Radiation for Removal of Pesticides from Waste Water. Journal of Physics, 49, 521533.

[18] Mackay, D., Freyberg, D., Roberts, P. and Cherry, J. (1986). A Natural Gradient Experiment on Solute Transport in a Sand Aquifer: Approach and Overview of Plume Movement. Water Resources Research, 22, 2017-2029.

[19] Bhatnagar, A. and Sillanpaa, M. (2010). Utilization of Agro-Industrial and Municipal Waste Materials as Potential Adsorbents for Water Treatment. Chemical Engineering Journal, 157, 277-296.

[20] Aksu, Z. and Yener, J. (1999). The Usage of Dried Activated Sludge and Fly Ash Wastes in Phenol Biosorption/Adsorption: Comparison with Granular Activated Carbon. Journal Environment Science Health Part A, 34, 1777-1796.

[21] Tan, I. A. W., Ahmad, A. L. and Hameed, B. H. (2008). Adsorption of Basic Dye on High Surface Area Activated Carbon Prepared from Coconut Husk: Equilibrium, Kinetic and Thermodynamic Studies. Journal of Hazardous Materials, 154, 337-346.

[22] Chin, J. (2011). Sarawak's Share in Malaysia Oil Palm. The Borneo Post, B1.

[23] Tan, I. A. W., Ahmad, A. L. and Hameed, B. H. (2009). Adsorption Isotherms, Kinetics, Thermodynamics and Desorption Studies of 2, 4, 6Trichlorophenol on Oil Palm Empty Fruit Bunch-Based Activated Carbon. Journal of Hazardous Materials, 164, $473-482$.

[24] Nuithitikul, K., Srikhun, S. and Hirunpraditkoon, S. (2010). Kinetics and Equilibrium Adsorption of Basic Green 4 Dye on Activated Carbon Derived from Durian Peel: Effects of Pyrolysis and Post-Treatment Conditions. Journal of the Taiwan Institute of Chemical Engineers, 41 , $591-598$.

[25] Langergren, S. and Svenska, B. K. (1898). Zur Theorie Der Sogenannten Adsorption Geloester Stoffe. Veternskapsakad Handlingar, $24,1-39$.

[26] Ho, Y. S. and McKay, G. (1998). The Kinetics of Sorption of Basic Dyes from Aqueous Solutions by Sphagnum Moss Peat. Canadian Journal of Chemical Engineering, 76 (4), 822-827.

[27] Hameed, B. (2007). Equilibrium and Kinetics Studies of 2,4,6-trichlorophenol Adsorption onto Activated Clay. Colloids and Surfaces A: Physicochemical and Engineering Aspect, 307, 45-52.

[28] Zawani, Z., Chuah, A. L. and Choong, T. S. (2009). Equilibrium, Kinetics and Thermodynamic Studies: Adsorption of Remazol Black 5 on the Palm Kernel Shell Activated Carbon (PKS-AC). European Journal of Scientific Research, 37, 63-71. 